\title{
Articles
}

\section{Jannemieke Owwerkerk" \\ The Potential of Mutual Recognition as a Limit to the Exercise of EU Criminalisation Powers}

\begin{abstract}
This paper discusses the relationship between on the one hand EU-wide harmonisation of substantive criminal law, and on the other, the principle of mutual recognition in the framework of transnational cooperation between EU Member States. It posits that the implementation of intensive cooperation regimes, based on the mutual recognition principle, limits the EU's criminalisation powers, especially under Articles 83(1) and 325(4) TFEU. If criminal prohibitions are adopted under the heading of these provisions, they cannot convincingly be founded on the wish to prevent forum shopping and facilitate judicial cooperation.
\end{abstract}

\section{Introduction}

A current debate has centred on how the European Union uses, and should use its criminalisation powers under the Lisbon Treaty. Whereas prior to Lisbon the discussion focused on the existence of competences to adopt Union-wide definitions of criminal offences, the post-Lisbon debate focuses on the exercise of these competences. Research in this area revolves around what is and should be required in order to consider the adoption of criminal prohibitions a legitimate choice. So far, most research has been reflecting on the requirements that are laid down in the relevant Treaty provisions, such as Article 83 Treaty on the Functioning of the European Union (TFEU). Less attention has been given to how these requirements have been interpreted by the EU legislature in practice; only with regard to some specific areas of crime, e.g. market

* Professor of European Criminal Law, Leiden Law School (j.w.ouwerkerk@law.leidenuniv.nl). This work is part of the research project 'Symbol or substance? Towards a systematic application of criminalisation criteria in EU Law', which is financed by the Netherlands Organisation for Scientific Research (NWO) under the Innovational Research Incentives Scheme (VENI grant, 2015-2017).

DOI: $10.5771 / 2193-5505-2017-1-5$ 
abuse, have a few analyses on this been carried out. ${ }^{1}$ The main objective of this paper is to reflect on two specific criminalisation grounds that have been invoked by the European Commission under Articles 83 and 325(4) TFEU, that is to say: the facilitation of judicial cooperation and the prevention of forum shopping.

The article examines whether and to what extent it is justified to invoke these aims for the underpinning of Union-wide criminal prohibitions. It argues that the implementation of the mutual recognition principle in the context of judicial cooperation between Member States, which is accompanied by far-reaching obligations to enforce each other's judicial decisions, invalidates to a certain extent the prevention of forum shopping and smoother judicial cooperation as legitimate arguments pro EU-level criminalisation. It is concluded that the mutual recognition principle must serve as a limit to the exercise of EU criminalisation powers.

This may sound odd since in the area of procedural criminal law the improvement of judicial cooperation and the facilitation of mutual recognition constitute the very rationale of the EU's mandate to adopt uniform rules, pursuant to Article 82(2) TFEU.2 One could raise the question why, by analogy within the field of procedural criminal law, the mutual recognition argument could not also justify harmonisation in the field of substantive criminal law, especially in view of the implicit reference in Article 82(1) TFEU to the approximation of substantive criminal law as part of the further implementation of the mutual recognition principle. ${ }^{3}$ But in this regard, it is important to mention that in the context of Article 82(2) TFEU, legal scholars have also criticized the application of the mutual recognition argument in the context of procedural criminal law. ${ }^{4}$ It has been argued that in the exercise of competences under Article 82(2) TFEU, a mere reference to a positive impact of common rules on the mutual recognition and judicial cooperation cannot suffice, for this would significantly extend the EU powers to legislate in this field. It has, therefore, been recommended that legislative action for the aim of facilitating mutual recognition requires sufficient evidence to

1 See, or instance: M. Miglietti, The First Exercise of Article 83(2) TFEU Under Review: An Assessment of the Essential Need of Introducing Criminal Sanctions, New Journal of European Criminal Law (NJECL) 2014, p. 5 et seq.; E. Herlin-Karnell, White-Collar Crime and European Financial Crises: Getting Tough on Market Abuse, European Law Review (ELR), 2012, p. 481 et seq.

2 See Article 82(2) TFEU: '2. To the extent necessary to facilitate mutual recognition of judgments and judicial decisions and police and judicial cooperation in criminal matters having a cross-border dimension, the European Parliament and the Council may, by means of directives adopted in accordance with the ordinary legislative procedure, establish minimum rules [...]'.

3 See Article 82(2) TFEU: 'Judicial cooperation in criminal matters in the Union shall be based on the principle of mutual recognition of judgments and judicial decisions and shall include the approximation of the laws and regulations of the Member States in the areas referred to in paragraph 2 and in Article 83 [...]'.

4 See J. Öberg, Subsidiarity and EU Procedural Criminal Law, European Criminal Law Review (EuCLR) 2015, p. 28-29, 40; V. Mitsilegas, The Symbiotic Relationship Between Mutual Trust and Fundamental Rights in Europe's Area of Criminal Justice, New Journal of European Criminal Law (NJECL) 2015, p. 476. 
demonstrate a link between the proposed procedural rights and the smoother application of the mutual recognition principle. ${ }^{5}$

This article aims to illustrate that the criticisms that have been expressed regarding harmonisation of procedural rights are also relevant in the field of substantive criminal law where mutual recognition-related arguments have also been invoked to justify harmonisation measures. In the absence of clear evidence that EU-level criminal prohibitions are necessary to improve judicial cooperation and to prevent forum shopping by criminals, the legitimacy of calling on these aims is problematic as such. But in this article, critical reflections are taken one step further: it is argued that it is the mutual recognition principle itself that limits the EU's power to create common definitions of offences.

The structure of this article is as follows. Section II provides an overview of postLisbon (proposals for) criminal prohibitions for which forum shopping prevention and/or smoother judicial cooperation were inter alia invoked to underpin the need to adopt those criminal prohibitions. Section III deals with the relevance of different scopes of criminal prohibitions under the current mutual recognition regime. Subsequently, Section IV examines the impact such differences may have on judicial cooperation and forum shopping, before presenting concluding remarks in Section V.

\section{Forum Shopping Prevention and Smoother Judicial Cooperation: Their Role in the EU's Exercise of Criminalisation Powers under the Lisbon Treaty}

This section provides an overview of proposed and adopted instruments in which either forum shopping prevention, or the facilitation of judicial cooperation, or both aims were referred to in order to underpin the need for criminal prohibitions. Because these instruments are based on either Article 83(1) TFEU, or Article 83(2) TFEU, or Article 325(4) TFEU, the following starts with a brief introduction on the competences laid down in these provisions.

Article 83 TFEU is the key provision in relation to EU-level criminalisation. Areas that expressly qualify for action under the first paragraph concern terrorism, trafficking in human beings, sexual exploitation of women and children, illicit drug trafficking, illicit arms trafficking, money laundering, counterfeiting of means of payment, computer crime, organised crime (Article 83(1) TFEU). In these areas of crime, Article 83(1) TFEU requires that the types of conduct to be prohibited have a cross-border dimension "resulting from the nature or impact of such offences or from a special need to combat them on a common basis". Pursuant to the second paragraph of Article 83 TFEU, the EU is also competent to act in several other policy areas; it concerns areas in which non-criminal harmonisation measures have already been taken, but where, in hindsight, criminal prohibitions are considered essential for the effective implementation of these harmonisation measures. Both paragraphs of Article 83 TFEU allow for minimum harmonisation by means of directives.

5 J. Öberg (fn. 4), p. 39-40.

EuCLR Vol. 7, 1/2017 
Outside the express criminalisation competences of Article 83 TFEU, several other treaty provisions may have the potential to serve as a legal basis for EU-level criminalisation. ${ }^{6}$ Of particular relevance to this paper is Article 325(4) TFEU that is widely acknowledged as allowing for the adoption of criminal prohibitions in the area of EUfraud. ${ }^{7}$ Such criminal prohibitions are not necessarily restricted to minimum norms in directives; instruments adopted based on Article 325(4) TFEU may also include supranational norms in regulations.

It needs no explanation that the sole existence of a legal basis for criminalisation does not automatically legitimise the actual creation of EU-level criminal prohibitions. The competence to design criminal prohibitions at the EU level is first and foremost governed by the subsidiarity principle, allowing the EU to act only if and insofar as the goals pursued by criminalisation cannot be achieved sufficiently at the Member States' level (Article 5(3) Treaty on European Union). Further constraints are to be found in the abovementioned provisions, such as the cross-border requirement (Article 83(1) TFEU), the harmonisation requirement (Article 83(2) TFEU), the necessity requirement (Article 325(4) TFEU) - just to name a few. But how are these requirements given substance to in practice?

Since the entry into force of the Lisbon Treaty, criminal prohibitions have been proposed and adopted under the headings of Articles 83 and 325(4) TFEU in several areas of crime: cybercrime, human trafficking, child sexual abuse, market abuse, EU-fraud, drug trafficking, and terrorism. The overview below demonstrates that, except for the areas of drug trafficking and terrorism, the objectives of forum shopping prevention and smoother judicial cooperation have been invoked to justify the creation of EUlevel criminal prohibitions. In such cases, it is argued that EU-level criminal prohibitions are needed in order to prevent offenders from moving to Member States with more lenient criminal laws, either to commit the crime there, or to escape justice. Or it is assumed that shared definitions of offences facilitate the options and willingness of Member States to cooperate in criminal affairs, i.e. to surrender suspects or transfer convicted people, to exchange information, or to gather evidence on the request of another Member State.

6 See, e.g., the extensive overview in J.W. Owwerkerk, Criminalisation Powers of the European Union and the Risks of Cherry-Picking Between Various Legal Bases: The Case for a Single Legal Framework for EU-Level Criminalisation, forthcoming in Columbia Journal of European Law (CJEL) 2017.

7 See amongst others: V. Mitsilegas, EU Criminal Law Competence After Lisbon: From Securitised to Functional Criminalisation, in: D. Acosta Arcarazo/C.C. Murphy (eds.), EU Security and Justice Law After Lisbon and Stockholm, 2014, p. 119; H. Satzger, International and European Criminal Law, 2012, p. 55; P. Asp, The Substantive Criminal Law Competence of the EU, 2012, p. 142. 
1. Criminalisation on the basis of Article 83(1) TFEU: cybercrime, human trafficking and child sexual abuse

\section{a) Directive 2013/40/EU on attacks against information systems}

The first directive adopted under the heading of Article 83(1) TFEU is Directive 2013/40/EU on cyber offences, i.e. attacks against information systems. ${ }^{8}$ Before the adoption of Directive 2013/40/EU, various criminal prohibitions in the area of attacks against information systems were in force already; pursuant to a 2005 Framework Decision, Member States were prescribed to criminalise the illegal access to information systems, illegal systems interference, and illegal data interference. ${ }^{9}$ In addition to these offences, Directive 2013/40/EU now obliges Member States to also criminalise the illegal interception of computer data (Article 6) as well as the act of making available tools (e.g. computer programmes) for the purpose of committing any of the offences covered by the 2005 Framework Decision and the new 2013 Directive (Article 7). ${ }^{10}$

In its initial proposal, accompanied by an Explanatory Memorandum and an Impact Assessment, the European Commission mentioned a number of reasons for why criminalisation of these offences would be necessary. It referred to technological developments, such as the increased criminal use of botnets, ${ }^{11}$ and the serious damage that large-scale attacks potentially cause ${ }^{12}$ Moreover, it was stated that further approximation in this area was needed to end the existing differences in national laws on the matter. Such differences were apparently held to hamper the fight against organised crime and terrorism as well as cross-border cooperation with regard to these crimes: "Significant gaps and differences in Member States' national laws [...] may hamper the fight against organised crime and terrorism, and may complicate effective police and judicial

8 Parliament and Council Directive 2013/40/EU on attacks against information systems and replacing Council Framework Decision 2005/222/JHA, OJ 2013 L 218/8.

9 Council Framework Decision 2005/222/JHA of 24 February 2005 on attacks against information systems, OJ 2005 L 69/67.

10 The relevant provisions of the 2005 Framework Decision (fn. 9) and the 2013 Directive (fn. 8) include inciting, aiding and abetting to any of the offences. Moreover, the 2005 Framework Decision criminalised attempts to the illegal interference of data and of information systems.

11 European Commission, Proposal for a Directive of the European Parliament and of the Council on attacks against information systems and repealing Council Framework Decision 2005/222/JHA, COM(2010) 517 final, in particular recital 2 of the proposed preamble and the Explanatory Memorandum on p. 2-3. See also: European Commission, Report to the Council based on Article 12 of the Council Framework Decision of 24 February 2005 on attacks against information systems (report on the 2005 Framework Decision), COM(2008) 448 final, par. 3.2; Commission Staff Working Document, Impact Assessment, Accompanying document to the Proposal for a Directive of the European Parliament and of the Council on attacks against information systems and repealing Council Framework Decision 2005/222/JHA, SEC(2010) 1122 final, paras 2.1 and 2.5.

$12 \operatorname{COM}(2010) 517$ (fn. 11), Explanatory Memorandum, p. 3; Impact Assessment SEC(2010) 1122 (fn. 11 ), para 2.1. 
cooperation in this area". ${ }^{13}$ How common norms are considered to facilitate the fight against organised crime and terrorism has not been explained immediately, but a crossreading of the various preparatory and legislative documents shows that this statement must be understood in view of the assumption that a decrease of national differences would prevent forum shopping: "[M]easures to decrease the fragmentation of criminal law and penalties would reduce the risk that the criminals will choose the location of their activities on the basis of the local criminal law ('forum shopping')". ${ }^{14}$

\section{b) Directive 2011/36/EU on trafficking in human beings}

Pursuant to Directive 2011/36/EU, Member States have to adopt a number of criminal prohibitions in the area of trafficking in human beings. ${ }^{15}$ These criminal prohibitions expand the scope of a 2002 Framework Decision that covers the most 'classical' forms of trafficking in human beings, that is to say, where people are recruited and trafficked using coercion, deception, fraud, or by abusing a person's vulnerability, for the purposes of forced labour, or sexual exploitation. ${ }^{16}$ In addition to these forms of human trafficking, Directive 2011/36/EU now prescribes Member States to also criminalise in their national laws the recruiting and trafficking of people for the purposes of forced begging, forced commission of criminal activities, or the removal of organs. ${ }^{17}$ In other words, the exploitation element of the 2002 Framework Decision has now been broadened and includes several other ways of exploitation.

A number of reasons underlie the decision to enact broader criminal prohibitions in the field of human trafficking, such as the wish to equal the Union-wide definition of human trafficking to the definitions provided for in a UN Protocol and a Council of Europe Convention on the matter ${ }^{18}$, and the alleged need to tackle recent developments in the phenomenon of human trafficking ${ }^{19}$. And specifically with regard to the

$13 \operatorname{COM}(2010) 517$ (fn. 11 ), recital 13 of the proposed preamble.

14 Impact Assessment SEC(2010) 1122 (fn. 11 ), para. 2.7.

15 Parliament and Council Directive 2011/36/EU on preventing and combating trafficking in human beings and protecting its victims, and replacing Council Framework Decision 2002/629/JHA, OJ 2011 L 101/1.

16 Council Framework Decision 2002/629/JHA, OJ 2002 L 203/1, Article 1. Pursuant to Article 2, Member States are also obliged to criminalise the instigation of, aiding, abetting or attempt to commit any of the offences covered by Article 1.

17 Directive 2011/36/EU (fn. 15), Article 2(3).

18 As provided for in the United Nations Protocol to Prevent, Suppress and Punish Trafficking in Persons, especially Women and Children, supplementing the UN Convention against Transnational Organized Crime, New York, 15 November 2000; and the Council of Europe Convention on Action against Trafficking in Human Beings, Warsaw, 16 May 2005. See Commission Staff Working Document, Impact Assessment, Accompanying document to the Proposal for a Directive of the European Parliament and of the Council on preventing and combating trafficking in human beings and protecting its victims, and replacing Council Framework Decision 2002/629/JHA, SEC(2009) 358, para. 4.3.

19 European Commission, Proposal for a Directive of the European Parliament and of the Council on preventing and combating trafficking in human beings and protecting its victims, 
proposed criminalisation of human trafficking for the purpose of removing organs, it was stated that such acts seriously violate human dignity and physical integrity, which justifies the prohibitions of those acts. ${ }^{20}$ Moreover, and particularly relevant in the framework of this paper, a further justification for proposed enhanced criminal prohibitions in this area follows from a statement that was made in the context of testing the subsidiarity principle. It was held that "[d]ifferences in legal treatment in the different Member States hinder coordinated efforts and hamper international law enforcement and judicial cooperation" and that the approximation of (inter alia) substantive criminal law "will have a positive impact on international law enforcement and judicial cooperation". ${ }^{21}$ Union-wide criminal prohibitions are thus assumed to facilitate transnational (judicial) cooperation and, therefore, to comply with the subsidiarity principle. ${ }^{22}$

\section{c) Directive 2011/92/EU on child sexual abuse}

While several forms of child sexual abuse and child sexual exploitation have been criminalised by EU law since 2004, a new instrument was considered necessary because the 2004 Framework Decision did not cover a number of serious forms of sexual abuse and sexual exploitation yet ${ }^{23}$, and because technological developments resulted in new forms of sexual abuse and exploitation - these not-yet-included and new forms of crime apparently needed to be criminalised by EU law as well. Directive 2011/92/EU was adopted, inter alia, for that aim. The newly covered offences concern behaviour in the sphere of sexual abuse, sexual exploitation, child pornography, and grooming. ${ }^{24}$

It follows from the initial proposal ${ }^{25}$ and the accompanying Impact Assessment that the further approximation of substantive criminal law in this area was held justified for

and replacing Council Framework Decision 2002/629/JHA, COM(2010) 95 final, recital 5 of the proposed preamble (the proposal was preceded by a proposal for a Framework Decision, $\operatorname{COM}(2009) 136$ final, but as a consequence of the entry into force of the Lisbon Treaty the proposal was changed into a proposal for a Directive). See also Directive 2011/36/EU (fn. 15), preamble, recital 11.

20 See $\operatorname{COM}(2010) 95$ (fn. 19 ), recital 5 of the proposed preamble and the Explanatory Memorandum on p. 7-8; Impact Assessment SEC(2009) 358 (fn. 18 ), in particular paras. 3, 4.3 and 6.4.4.1; Directive 2011/36/EU (fn. 15), preamble, recital 11.

$21 \operatorname{COM}(2010) 95$ (fn. 19), Explanatory Memorandum, para. 4.

22 Id.

23 Council Framework Decision 2004/68/JHA, OJ 2004 L 13/44.

24 Parliament and Council Directive 2011/92/EU on combating the sexual abuse and sexual exploitation of children and child pornography, and replacing Council Framework Decision 2004/68/JHA, OJ 2011 L 335/1, Articles 3-6. Because of the high number of criminal prohibitions, their contents will not be described in detail in this paper. However, it is worth mentioning here that inciting, aiding and abetting to the newly criminalised offences must constitute criminal offences as well (Article 7(1)). Moreover, attempts to some of the newly criminalised offences has also been prohibited (Article 7(2)).

25 European Commission, Proposal for a Directive of the European Parliament and of the Council on combating the sexual abuse and sexual exploitation of children and child pornography, and replacing Council Framework Decision 2004/68/JHA, COM(2010) 94 final (the proposal was originally submitted as a draft Framework Decision, COM(2009) 135 final), 
a number of reasons, such as the "long-term physical, psychological and social harm to victims", ${ }^{26}$ and to be able to effectively prosecute these crimes. In the context of the latter point, the issues of forum shopping prevention and facilitation of judicial cooperation came up. It was held that common definitions of offences would prevent criminals from choosing the Member States with more lenient criminal laws to commit their crimes, would simplify the collection of comparable data and experience, and would facilitate transnational cooperation (in particular extradition and mutual legal assistance). ${ }^{27}$

2. Criminalisation on the basis of Article 83(2) TFEU: Directive 2014/57/EU on market abuse

Directive 2014/57/EU obliges the Member States to prohibit by means of criminal law the following acts when they are committed intentionally: insider dealing (including recommending or inducing another person to engage in insider dealing), unlawful disclosure of inside information, and market manipulation. ${ }^{28}$

In the context of market abuse, EU-level criminal law measures had not previously been taken; prior to the adoption of Directive 2014/57/EU, the combat of market abuse has been effectuated outside the criminal law sphere, mainly by means of prescribing administrative sanctions. Criminal sanctions would, however, be needed because they would demonstrate a stronger social disapproval than administrative sanctions or compensation mechanisms under civil law, decrease the negative effects of market abuse on the single market ${ }^{29}$ and, furthermore, because common rules in this

but following the entry into force of the Lisbon Treaty, the proposal was amended into a draft Directive).

$26 \operatorname{COM}(2010) 94$ (fn. 25), Explanatory Memorandum, para. 1 on p. 2. See also Commission Staff Working Document, Impact Assessment, Accompanying document to the Proposal for a Directive of the European Parliament and of the Council on combating the sexual abuse and sexual exploitation of children and child pornography, and replacing Council Framework Decision 2004/68/JHA, SEC(2009) 355 final, paras 2.2.

$27 \operatorname{COM}(2010) 94$ (fn. 25), Explanatory Memorandum, para. 1 on p. 2, and Impact Assessment SEC(2009) 355 (fn. 26 ), paras. 2.2, 2.4, 3.1, and 4.3.

28 Parliament and Council Directive 2014/57/EU on criminal sanctions for market abuse, OJ 2014 L 173/179, Articles 3-5. Pursuant to Article 6, the prohibited conduct also covers the inciting, aiding, and abetting to several forms of insider dealing, unlawful disclosure of inside information, and market manipulation, as well as attempts to several forms of insider dealing and market manipulation.

29 European Commission, Proposal for a Directive of the European Parliament and of the Council on criminal sanctions for insider dealing and market manipulation, $\operatorname{COM}(2011) 654$ final (later on amended by $\operatorname{COM}(2012) 420$ final), Explanatory Memorandum, par 1 on p. 3, and recital 5-7 of the proposed preamble. Commission Staff Working Document, Impact Assessment, Accompanying document to the Proposal for a Regulation of the European Parliament and of the Council on insider dealing and market manipulation (market abuse) and the Proposal for a Directive of the European Parliament and of the Council on criminal sanctions for insider dealing and market manipulation, SEC(2011) 1217 final, para. 3.2.3 and Annex 8 on p. 168. 
area, decrease the risk of forum shopping and facilitate cooperation between law enforcement authorities ${ }^{30}$.

During negotiations within the Parliament, the aim of decreasing the risk of forum shopping received special attention. In its adoption at first reading, the Parliament appeared to be in favour of an explicit reference in the Directive's preamble to the risk of forum shopping in the absence of harmonised rules, and proposed to include an additional phrase, stating that "the absence of common criminal sanction regimes across the Union creates opportunities for perpetrators of market abuse to take advantage of lighter regimes in some Member States”. ${ }^{31}$ In my view, this underlines that a significant number of Parliamentarians consider the determent of forum shopping an appropriate ground to criminalise market abuse-related conduct at the EU level. The proposed addition was included in the adopted Directive. ${ }^{32}$

The aim to decrease the risk of forum shopping was presented by the Commission under the heading of the effectiveness condition of Article 83(2) TFEU. This very argument was, however, sharply criticised by the German Federal Council (Bundesrat) which submitted a reasoned opinion on why it considered the Commission's proposal not compliant with the principle of subsidiarity. ${ }^{33}$ According to the Bundesrat, the proposal does not address the question of whether and why common minimum norms in this regard would be "essential" for the effective implementation of the Union's policy to protect market integrity. In view of the Bundesrat, the essential nature of common minimum norms can neither be found in the mere statement that common minimum norms are expected to have a positive influence on market integrity, nor in the "mere theoretical possibility" of forum shopping. With regard to this latter issue, the Bundesrat argued that such a general and theoretical remark may be mentioned in the context of many other areas of crime and is as such, inadequate to demonstrate the essential nature of the proposed common norms. The Commission disagreed; in its opinion, it has sufficiently proven the essential nature of the proposed measures. ${ }^{34}$

$30 \operatorname{COM}(2011) 654$ (fn. 29), recital 7 of the proposed preamble and Explanatory Memorandum, par. 1 on p. 3; Impact Assessment SEC(2011) 1217 (fn. 29 ), para. 3.2.3, and Annex 8 on p. $167-168$.

31 European Parliament Committee on Economic and Monetary Affairs, Report of 19 October 2012, A7-0344/2012, proposed recital 9a.

32 Directive 2014/57/EU (fn. 28), preamble, recital 7.

33 See: http://www.europarl.europa.eu/meetdocs/2009_2014/documents/juri/cm/887/887973/8 87973 en.pdf (last accessed on 20 August 2015). The reasoned opinion was submitted under Article 6 of Protocol No. 2 on the application of the principles of subsidiarity and proportionality.

34 See document C(2012) 5656 final of 5 September 2012, http://dipbt.bundestag.de/doc/brd/20 12/0529-12.pdf (in German). 
3. Criminalisation on the basis of Article 325(4) TFEU: Draft Directive COM(2012) 363 on EU-fraud

In 2012, the European Commission submitted a proposal for a Directive to criminalise serious cases of EU-fraud as well as fraud-related acts that negatively affect the EU budget (such as money laundering and corruption). ${ }^{35}$ The proposed Directive intends to replace the 1995 PIF Convention ${ }^{36}$ and its two Protocols ${ }^{37}$ through which almost all of the Member States are already obliged to impose criminal sanctions for the aforementioned activities. ${ }^{38}$

The 2012 draft Directive is currently in the late stage of negotiations; one of the issues that has been hotly debated concerns VAT fraud. Probably because VAT fraud affects the national budget to a far larger extent than the EU budget, the Council has argued against including VAT evasion in the concept of EU fraud. In 2015, however, in its judgment in the Taricco case, the ECJ has rules that "fraud" in the sense of the PIF Convention (defined in Article 1) does cover VAT evasion. ${ }^{39}$ It now remains to be seen how this judgment will affect the remaining negotiations on the proposed Directive. ${ }^{40}$

The European Commission invokes a number of reasons why criminal measures should be established in the area of EU-fraud. For instance, it refers to the serious financial damage EU-fraud would cause to the detriment of the EU budget, and thereby, to taxpayers ${ }^{41}$, and states that equivalent protection across the $\mathrm{EU}$ of its financial interests would benefit the credibility of EU finance..$^{42}$ Moreover, it is held that criminalisation in this area is necessary for the effectiveness of the Union's policy to protect its own financial interests. In this regard, it is argued that common offences would "strengthen the deterrent effect and enforcement potential of relevant provisions, and reduce the incentive for potential perpetrators to move to more lenient jurisdictions within the Union to exercise their intentional illegal activities". ${ }^{43}$ Furthermore, it has been stated in the Impact Assessment that "criminal law set out at EU level can be an

35 European Commission, Proposal for a Directive of the European Parliament and of the Council on the fight against fraud to the Union's financial interests by means of criminal law, $\operatorname{COM}(2012) 363$ final.

36 OJ 1996 C 316/49.

37 Protocol No. 1 to the PIF Convention obliges criminal sanctions for passive and active corruption which damages the EU's financial interests, OJ 1996 C 313/1; Protocol No. 2 to the PIF Convention requires to impose criminal sanctions for money laundering activities which damages the EU financial interests, OJ 1997 C 221/12.

38 Except for Croatia and the UK, the PIF Convention applies to all EU Member States.

39 European Court of Justice (ECJ) 8.9.2015, case 105/14 (criminal proceedings against Ivo Taricco and others), ECLI:EU:C:2015:555, margin no. 41.

40 See Council document 9804/16 for the latest developments in the discussion.

$41 \operatorname{COM}(2012) 363$ (fn. 35), Explanatory Memorandum, par. 1.1 on p. 2. See also Commission Staff Working Document, Impact Assessment, Accompanying document to the Proposal for a Directive of the European Parliament and of the Council on the protection of the financial interests of the European Union by criminal law, SDW(2012) 195 final, Part I, par. 4 on p. 28.

$42 \operatorname{COM}(2012) 363$ (fn. 35), Explanatory Memorandum, par. 1.1 on p. 4; Impact Assessment SDW(2012) 195, Part I (fn. 41 ), par. 1, and par. 4 on p. 28.

$43 \operatorname{COM}(2012) 363$ (fn. 35), Explanatory Memorandum, par. 1.1 on p. 3-4. 
essential contribution in that it helps to reduce disparities across the normative landscape of the EU and this encourages judiciaries of the Member States to cooperate better". ${ }^{44}$

\section{The Limited Relevance of Diverging Scopes of Criminal Probibitions under the Mutual Recognition Principle}

It follows from what precedes that the aims of forum shopping prevention and the improvement of judicial cooperation are considered relevant for the underpinning of EUlevel criminal prohibitions under the headings of Articles 83 and 325 TFEU. In almost all of the crime areas in which criminal prohibitions have been suggested since the entry into force of the Lisbon Treaty, both objectives have been invoked. In the areas of child sexual abuse and EU-fraud, both issues are defended under a criterion of effectiveness; in the context of child sexual abuse this effectiveness criterion refers to the effective prosecution of sexual offences against children ${ }^{45}$, whereas effectiveness in the area of EU-fraud, more generally, refers to the effective protection of the EU budget. ${ }^{46}$ In the other areas, the avoidance of forum shopping and the improvement of judicial cooperation have been called on autonomously.

In this section it will be examined whether and to what extent both objectives can justify the harmonisation of definitions of offences in the European Union. To that end, it will assess if the claim that diverging scopes of national criminal prohibitions would hamper transnational cooperation between Member States and would maintain, or even encourage forum shopping across the EU Member States, can reasonably be upheld under the current state of play in EU criminal law.

Within the context of national law-making in the field of substantive criminal law, various theories have been developed over time providing guidelines on how to shape a balanced criminal law. Whilst several differences do exist between these theories, a significant majority agrees on that the criminal law should only be called on as a last resort, and that in any case the unwanted behaviour is wrong and causes harm. ${ }^{47}$ In addition to those fundamental aspects, also more practical aspects, such as the frequency of conduct and the enforceability of a proposed criminal prohibition in practice, have been recognised as relevant notions that deserve explicit consideration before adopting

44 Impact Assessment SDW(2012) 195, Part I (fn. 41 ), par. 3.1 on p. 9. Most probably, the aim to 'contribute to increasing mutual trust between the Member States' judiciaries' must be interpreted as related to the aim of encouraging judicial cooperation, see par. 4 on p. 28.

45 See above Section I (1) (c).

46 See above Section I (3).

47 To mention only a selection of outstanding academic sources: A.P. Simester E A. von Hirsch, Crimes, Harms and Wrongs. On the Principles of Criminalisation, 2012; N. Persak, Criminalising Harmful Conduct. The Harm Principle, its Limits and Continental Counterparts, 2007; N. Jareborg, Criminalization as Last Resort (Ultima Ratio), Ohio State Journal of Criminal Law 2005, p. 521 et seq.; D. Husak, The Criminal Law as Last Resort, Oxford Journal of Legal Studies 2004-2, p. 207 et seq.; J. Feinberg, The Moral Limits of the Criminal Law, Vol. 1-4, 1984, 1985, 1986, and 1988.

EuCLR Vol. 7, 1/2017 
new criminal prohibitions. ${ }^{48}$ The issues of forum shopping prevention and the facilitation of judicial cooperation between nation-states have - for obvious reasons - never been mentioned in this regard. It does, however, seem obvious why these issues could be relevant in the context of law-making at the EU level since EU law automatically affects the national laws of multiple states. Everyone with a fair share of common sense understands that, for child pornography producers, there is no sense in moving from Member State A to Member State B if the production of child pornography also constitutes a criminal offence in Member State B. Moreover, it is easy to imagine that the authorities of Member State $\mathrm{C}$ would be more willing to enforce a custodial sanction handed down by a judge in Member State $\mathrm{D}$ if the underlying behaviour is also criminally prohibited in State C's domestic legal order. To have justice done, it is, therefore, tempting to support the further development of shared definitions of offences across the EU in order to disable perpetrators from selecting Member States with more narrower definitions of offences to commit their crimes, or to flee to in order to escape justice, and in order to facilitate Member States to cooperate in the prosecution, adjudication and sanctioning of criminal offences.

Though seemingly reasonable at first sight, it will be argued below that such an argumentation is untenable to a significant extent, for it ignores the extensive possibilities and obligations Member States have to cooperate with each other and to prevent the existence of safe havens for criminals across the EU.

\section{The principle of mutual recognition in criminal justice cooperation}

Over the past decades, the legislative framework for judicial cooperation in criminal affairs has significantly been intensified and simplified, mainly as a result of the implementation of the principle of mutual recognition. Based on the presumption of a high level of mutual trust amongst the that Member States in each other's criminal justice systems, the principle of mutual recognition basically envisages a "free movement of judicial decisions" ${ }^{49}$. Presently, a variety of judgments and judicial decisions - from custodial sanctions to alternative and conditional sentences, and from arrest warrants to supervision measures pending court proceedings - qualify for execution outside the Member State in which they were handed down, with a minimum of formalities and a limited number of exceptions compared to traditional cooperation instruments. ${ }^{50}$

48 For instance in: K. Svatikova, Economic criteria for criminalization. Optimizing Enforcement in Case of Environmental Violation, 2011; Th. A. de Roos, Strafbaarstelling van economische delicten, 1987 (only available in Dutch); L.H.C. Hulsman, Handhaving van recht, 1965 (only available in Dutch).

49 See Council Framework Decision 2002/584/JHA on the European arrest warrant and the surrender procedures between Member States, OJ 2002 L 190/1, preamble, recital 5.

50 For further reading on mutual recognition in the criminal law context, see: W. van Ballegooij, The Nature of Mutual Recognition in EU Law, 2015; A. Suominen, The Principle of Mutual Recognition in Cooperation in Criminal Matters, 2011; C. Janssens, The Principle of Mutual Recognition in EU Law, 2013, and J. Owwerkerk, Quid Pro Quo? A comparative law perspective on the mutual recognition of judicial decisions in criminal matters, 2011. 
One of the main reasons the European Council decided back in 1999 that judicial cooperation in criminal matters between EU Member States should be governed by the recognition principle was that, in the area without internal frontiers, safe havens for criminals should be avoided. ${ }^{51}$ The right to move and reside freely throughout the territory of the entire Union should, after all, not benefit criminals too easily. Before 1999, this aim was initially strived for by means of proposals to approximate the substantive criminal laws of the Member States. Because these efforts were not as successful as expected, it was decided to improve the system of cooperation between Member States. ${ }^{52}$ The result would be equal - i.e. criminals would not be able to escape justice but Member States would remain free to define the scopes of criminal prohibitions. ${ }^{53}$ It goes without saying that, if only from this historical perspective, it is hard to justify today's reasoning that the approximation of criminal prohibitions is needed in order to avoid forum shopping and to smoothen judicial cooperation; the mutual recognition principle was introduced in the criminal law sphere exactly for these aims.

2. The partial abolishment of the double criminality requirement under the mutual recognition regime

The historical background aside, the question arises whether and to what extent the application of the mutual recognition principle may lead to situations in which sought persons or convicted criminals de facto go unpunished, due to divergences in the scopes of national criminal prohibitions. It is, after all, the very rationale of the mutual recognition principle that Member States are, in principle, obliged to enforce foreign judgments and judicial decisions if another issuing Member State requests so, irrespective of whether the underlying offence also constitutes a crime in the domestic legal order. Only under limited circumstances are Member States allowed to decline cooperation. ${ }^{54}$

Particularly relevant in the context of this paper is the partial abolition of the double criminality requirement. This fundamental principle was, to a large extent, considered

51 Tampere European Council 15 and 16 October 1999, 'Presidency Conclusions', margin no. 33-37.

52 S. Alegre/M. Leaf, Mutual Recognition in European Judicial Cooperation: A Step Too Far Too Soon? Case Study - The European Arrest Warrant, European Law Journal (ELJ) 2004, p. 200 et seq.

53 See European Commission, Communication to the Council and the European Parliament, Mutual Recognition of Final Decisions in Criminal Matters, $\operatorname{COM}(2000) 495$ final, p. 4 ("Based on this idea of equivalence and the trust it is based on, the results the other state has reached are allowed to take effect in one's own sphere of legal influence. On this basis, a decision taken by an authority in one state could be accepted as such in another state, even though a comparable authority may not even exist in that state, or could not take such decisions, or would have taken an entirely different decision in a comparable case" and "...mutual recognition can to some degree make standardisation unnecessary").

54 See for an overview A. Klip, European Criminal Law. An Integrative Approach, $3^{\text {rd }}$ ed., 2016, p. 412 et seq. 
outdated in the specific context of the EU in which a high level of mutual trust was assumed to exist amongst the Member States in each other's criminal justice systems. Almost all mutual recognition instruments, therefore, prohibit, in principle, the verification of double criminality in the executing Member State regarding as much as 32 offence categories; the only instrument that fully accepts that mutual recognition is made conditional upon double criminality is the 2011 Directive on the European protection order. ${ }^{55}$

The 2002 Framework Decision on the European arrest warrant (hereinafter: "FD EAW") $)^{56}$, which is the first mutual recognition instrument, has set the example for most of the instruments that were adopted afterwards. Article 2(2)FD EAW determines that the issuing Member State may not refuse recognition on the ground that the offence that underlies the European arrest warrant does not constitute a crime in domestic legal order if this offence falls under one of the following areas of crime:

1. participation in a criminal organization

2. terrorism

3. trafficking in human beings

4. sexual exploitation of children and child pornography

5. illicit trafficking in narcotic drugs and psychotropic substances

6. illicit trafficking in weapons, munitions and explosives

7. corruption

8. fraud, including that affecting the EU financial interests

9. laundering of the proceeds of crime

10. counterfeiting currency

11. computer-related crime

12. environmental crime

13. facilitation of unauthorised entry and residence

14. murder

15. grievous bodily injury

16. illicit trade in human organs and tissue

17. kidnapping, illegal restraint and hostage-taking

18. racism and xenophobia

19. organised or armed robbery

20. illicit trafficking in cultural goods

21. swindling

22. racketeering and extortion

23. counterfeiting and piracy of products

24. forgery of administrative documents and trafficking therein

25. forgery of means of payment

55 Parliament and Council Directive 2011/99/EU on the European protection order, OJ $2011 \mathrm{~L}$ $338 / 2$, Article 10(1)(c).

56 Framework Decision 2002/584/JHA (fn. 49). 
26. illicit trafficking in hormonal substances and other growth promoters

27. illicit trafficking in nuclear or radioactive materials

28. trafficking in stolen vehicles

29. rape

30. arson

31. crimes within the jurisdiction of the International Criminal Court

32. unlawful seizure of aircraft/ships, sabotage

If a European arrest warrant is issued in relation to an offence that falls under one of these categories of crime, the executing Member State is, in principle, held to surrender the sought person thus, provided of course that all other terms of the FD EAW are met. This equally applies with regard to freezing orders ${ }^{57}$, confiscation orders ${ }^{58}$ and financial penalties, though with regard to the latter type of sanctions, the double criminality requirement has been abolished for an even longer list of crime categories ${ }^{59}$.

The same list of offence categories has also been included in the instruments that apply the mutual recognition principle to custodial sanctions ${ }^{60}$, probations decisions and alternative sanctions ${ }^{61}$, and supervision measures ${ }^{62}$. However, these three instruments do allow Member States to declare to preserve the double criminality requirement nonetheless. In relation to custodial sanctions, as much as 12 Member States have notified the Council that they will apply the double criminality requirement. ${ }^{63} \mathrm{~A}$ much

57 Council Framework Decision 2003/577/JHA on the execution in the European Union of orders freezing property or evidence, OJ 2003 L 196/45, Article 3(2).

58 Council Framework Decision 2006/783/JHA on the application of the principle of mutual recognition to confiscation orders, OJ 2006 L 328/59, Article 6(1).

59 Council Framework Decision 2005/214/JHA on the application of the principle of mutual

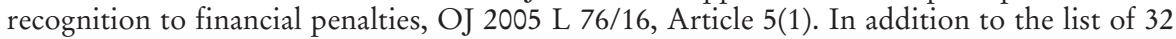
areas of crime, this provision also covers: conduct which infringes road traffic regulations (including breaches of regulations pertaining to driving hours and rest periods and regulations on hazardous goods); smuggling of goods; infringements of intellectual property rights; threats and acts of violence against persons (including violence during sport events); criminal damage; theft; offences established by the issuing State and serving the purpose of implementing obligations arising from instruments adopted under the EC Treaty or under Title VI of the EU Treaty.

60 Council Framework Decision 2008/909/JHA on the application of the principle of mutual recognition to judgments in criminal matters imposing custodial sentences or measures involving deprivation of liberty for the purpose of their enforcement in the European Union, OJ 2008 L 327/27, Article 7(1).

61 Council Framework Decision 2008/947/JHA on the application of the principle of mutual recognition to judgments and probation decisions with a view to the supervision of probation measures and alternative sanctions, OJ $2008 \mathrm{~L} \mathrm{337/102,} \mathrm{Article} \mathrm{10(1).}$

62 Council Framework Decision 2009/829/JHA on the application, between Member States of the European Union, of the principle of mutual recognition to decisions on supervision measures as an alternative to provisional detention, OJ 2009 L 294/20, Article 14(1).

63 It concerns: Czech Republic, Germany, France, Croatia, Ireland, Lithuania, Hungary, Netherlands, Austria, Poland, Romania, and Slovenia. See: General Secretariat of the Council, Note on Council Framework decision 2008/909/JHA - Declarations under Article 7(4) and Article 28(2), Council doc. 9603/16. 
smaller number of six Member States delivered such declaration with regard to probation measures and alternative sanctions ${ }^{64}$, whereas five Member did so in relation to supervision measures ${ }^{65}$.

In the context of cross-border evidence gathering, executing authorities are only allowed to verify double criminality in a limited number of cases. The 2014 Directive on the European investigation order - replacing the multilateral legal framework regarding mutual legal assistance as well as the EU instruments on mutual recognition of freezing orders ${ }^{66}$ and evidence warrants ${ }^{67}$ - determines that the carrying out of foreign investigative measures may not be made subject to the requirement of double criminality if these measures concern: the obtaining of information or evidence already in the possession of the executing; the obtaining of information contained in databases held by police or judicial authorities and directly accessible by the executing authority in the framework of criminal proceedings; the hearing of a witness, expert, victim, suspected or accused person or third party in the territory of the executing State; any non-coercive investigative measure as defined under the law of the executing State; and the identification of persons holding a subscription of a specified phone number or IP address). In relation to other types of investigative measures, particularly coercive measures such as search and seizure, the double criminality requirement may only be applied if the foreign measure relates to an offence that falls outside the abovementioned list of 32 offence categories. ${ }^{68}$

64 It concerns: Czech Republic, Germany, Lithuania, Hungary, Netherlands, and Poland. See: Commission Staff Working Document, Tables 'State of play' and 'Declaration' accompanying the Report from the Commission on the implementation by the Member States of the Framework Decisions 2008/909/JHA, 2008/947/JHA and 2009/829/JHA on the mutual recognition of judicial decisions on custodial sentences or measures involving deprivation of liberty, on probation decisions and alternative sanctions and on supervision measures as an alternative to provisional detention, SDW(2014) 34 final, p. 8-12; Ministry of Justice of the Republic of Lithuania, Notification of the transposition of Framework Decisions 2008/909/ JHA, 2008/947/JHA and 2009/829/JHA, Council doc. 5798/15, Annex II, p. 7; Permanent Representation of the Federal Republic of Germany to the European Union, Note on Council Framework Decision 2008/947/JHA - Notification and Implementation made by Germany, Council doc. 5901/16, p. 2; Permanent Representation of the Czech Republic to the European Union, Note on implementation of the Council Framework Decision 2008/947/JHA - Notification by the Czech Republic, Council doc. 7044/1/14, Annex 2, p. 20.

65 It concerns: Germany, Lithuania, Hungary, Poland, and Romania. See: Tables 'State of play' and 'Declaration SDW(2014) 34 (fn. 64), p. 13-18; Permanent Representation of Romania to the European Union, Note on implementation of the Council Framework Decision 2009/829/JHA - Notification by Romania, Council doc. 5685/14, p. 3.

66 Framework Decision 2003/577/JHA (fn. 57).

67 Council Framework Decision 2008/978/JHA regarding the cross-border obtaining of already existing evidence, OJ $2008 \mathrm{~L}$ 350/72.

68 Parliament and Council Directive 2014/41/EU regarding the European Investigation Order in criminal matters, OJ $2014 \mathrm{~L}$ 130/1, Article 11(2)(g) in conjunction with Article 10(2). Pursuant to Article 36, the deadline for implementation is 22 May 2017. According to the latest information on the website of the European Judicial Network, none of the Member States have communicated national implementation measures, see https://www.ejn-crimjust.europa 
3. EU criminalisation powers and the list of offences for which double criminality may no longer be required: overlapping crime categories

It is worth underlining that the aforementioned list of 32 offences must be interpreted as referring to 32 offence categories, or, put differently, areas of crime. The verbatim texts of the key provisions on double criminality in the respective mutual recognition instruments might suggest otherwise because of the use of the term "offences" 69 which possibly creates the impression that the list "only" covers behaviour for which equal definitions of offences exist in the national laws of the Member States. Such an interpretation could also be read in the words of those who state that the practical value of the partial abolishment of the double criminality requirement should not be overestimated since nearly all of the offences on the list do already constitute a criminal offence in the Member States. ${ }^{70}$ Given, however, that the relevant mutual recognition instruments use the terms "categories of offence" where they mention the Council's competence to extend the list of offences ${ }^{71}$, it must be concluded that the partial abolishment of the double criminality requirement applies to 32 listed areas of crime rather than to transnationally defined definitions of offences. Somewhat implicitly, this has been confirmed by the European Court of Justice's ruling in the Advocaten voor de Wereld-case. In seeking the annulment of the Belgian implementation legislation of the Framework Decision on the European arrest warrant, the organisation Advocaten voor de Wereld claimed that Article 2(2) of this Framework Decision violates the legality principle because the list of offences contained therein fails to provide for "offences having a sufficiently clear and precise legal content", rather lists "only vague categories of undesirable behaviour". ${ }^{72}$ The European Court of Justice, however, held that Article 2(2) does not infringe the legality principle, because it is the nationally defined offence underlying the European arrest warrant that must conform to the principle of legality (pursuant to the Member States' obligations arising under Article 6 TEU), and that these national definitions must serve as a point of reference in determining whether the underlying offence falls under one of the listed categories of crime:

.eu/ejn/EJN_Library_StatusOfImpByCat.aspx?CategoryId=120 (last accessed on 1 September 2016).

69 See for instance Framework Decision 2002/584/JHA on the European arrest warrant (fn.49), Article 2(2): "The following offences, if they are punishable in the issuing Member State by a custodial sentence or a detention order for a maximum period of at least three years and as they are defined by the law of the issuing Member State, shall, under the terms of this Framework Decision and without verification of the double criminality of the act, give rise to surrender pursuant to a European arrest warrant...” (italics added).

70 See, for instance, Klip (fn. 54), p. 403 et seq.; G. Vermeulen, 'How Far Can We Go in Applying the Principle of Mutual Recognition?', in: C. Fijnaut/J. Ouwerkerk (eds.), The Future of Police and Judicial Cooperation in the European Union, 2010, p. 243.

71 See, for instance, Framework Decision 2002/584/JHA on the European arrest warrant (fn. 49 ), Article 2(3). The same terminology has been used in corresponding provisions in the other relevant instruments. (emphasis added.).

72 European Court of Justice (ECJ) 3.5.2007, case 303/05 (Advocaten voor de Wereld VZW/ Leden van de Ministerraad), ECLI:EU:C:2007:261, margin no. 13.

EuCLR Vol. 7, 1/2017 
"[...] even if the Member States reproduce word-for-word the list of the categories of offences set out in Article 2(2) of the Framework Decision for the purposes of its implementation, the actual definition of those offences and the penalties applicable are those which follow from the law of 'the issuing Member State'. The Framework Decision does not seek to harmonise the criminal offences in question in respect of their constituent elements or of the penalties which they attract. Accordingly, while Article 2(2) of the Framework Decision dispenses with verification of double criminality for the categories of offences mentioned therein, the definition of those offences and of the penalties applicable continue to be matters determined by the law of the issuing Member State, which [...] must respect fundamental rights and fundamental legal principles as enshrined in Article $6 E U$, and, consequently, the principle of the legality of criminal offences and penalties" (italics added). ${ }^{73}$

Thus, whereas the executing Member State is allowed to verify if the underlying criminal offence, as defined in the law of the issuing Member State, can be brought under the heading of one of the crime categories on the list, it is not allowed to verify whether this underlying act has also been criminalised in its own legal order. As a result, the mere existence of divergences in the scopes of national criminal prohibitions has become irrelevant if the underlying offence falls under one of these areas of crime obviously only and insofar as the list of offences has been included in the applicable instrument and is being applied by the executing Member State involved; then, mutual recognition cannot be refused on the sole ground that the underlying offence does not constitute a criminal offence in the domestic legal order. ${ }^{74}$

In view of what had been discussed above, the question arises what the previous findings mean for the exercise of criminalisation competences under Articles 83 and 325 TFEU. To what extent could the prevention of forum shopping as well as the facilitation of judicial cooperation credibly be invoked in areas of crime in which double criminality may not be verified by the executing authorities? In order to answer this question, it is necessary, firstly, to make a comparison between, on the one hand, the list of offences as included in the various mutual recognition instruments and, on the other, the areas of crime as to which criminalisation competences have been provided for in the Lisbon Treaty. As shown, the Lisbon Treaty envisages several legal bases for the adoption of EU-level criminal prohibitions. ${ }^{75}$ It has also been demonstrated that, since the entry into force of the Lisbon Treaty, the EU has exercised its criminalisation powers under the heading of two of these provisions; that is to say Article 83 TFEU and Article 325 TFEU.

73 ECJ, Advocaten voor de Wereld VZW/Leden van de Ministerraad (fn. 72), margin no. 52-53.

74 To qualify for refusal the lack of double criminality must be accompanied by the circumstance that the offence has partly or wholly been committed outside the territory of the issuing Member State, and only under a limited number of mutual recognition instruments at that, see infra Section III.4.

75 See Section II. 
The criminalisation competence laid down in Article 83 TFEU covers several areas of crime. It has been mentioned before that the first paragraph of this provision needs to be distinguished from its second paragraph since both serve different objectives. ${ }^{76}$ Article 83(1) TFEU, to start with, provides a competence to enact common definitions of offences in 10 expressly enumerated areas of crime in which EU-level criminal prohibitions area held to be required because of the "particularly serious nature" of these types of behaviour, and because of their "cross-border dimension". According to Article 83(1) TFEU itself, the cross-border dimension of those crimes may follow from their nature or impact or from a "special need to combat them on a common basis". The areas of crime that expressly qualify for action under the heading of this provision are:

\section{Terrorism}

2. Trafficking in human beings

3. Sexual exploitation of women and children

4. Illicit drug trafficking

5. Illicit arms trafficking

6. Money laundering

7. Corruption

8. Counterfeiting of means of payment

9. Computer crime

10. Organised crime

When this list of crime areas is collated with the list of offence categories for which double criminality may no longer be verified, it is clear that all of the crime areas of Article 83(1) TFEU are found on this list of offence categories.

The second paragraph of Article 83 TFEU provides an express legal basis for regulatory criminal law. Under its heading, EU-level criminal prohibitions may be created to serve the effectiveness of EU law in harmonised policy areas. These areas have not expressly been mentioned, but they obviously include a wide range of EU policy areas, such as, inter alia, environmental protection, market integrity, racism and xenophobia, fisheries policy, or the protection of the EU's financial interests. ${ }^{77}$ If a list of (potential) crime areas that qualify for action under Article 83(2) TFEU is collated with the list of offence categories for which the verification of double criminality has been abolished,

76 See also V. Mitsilegas, EU Criminal Law Competence After Lisbon: From Securitised to Functional Criminalisation, in: D. Acosta Arcarazo/C.C. Murphy (eds.), EU Security and Justice Law After Lisbon and Stockholm, 2014.

77 This follows from European Commission, Communication to the European Parliament, the Council, the European Economic and Social Committee and the Committee of the Regions, Towards an EU Criminal Policy: Ensuring the effective implementation of EU policies through criminal law, COM(2011) 573 final, p. 10-11. See also Section II.2 on the post-Lisbon initiative to adopt criminal prohibitions in order to preserve market integrity (on the basis of Article 83(2) TFEU). 
it appears that criminal offences in some of the abovementioned areas of crime do appear on the list of offence categories (e.g. environmental crime, racism and xenophobia, EU-fraud) while criminal offences in some other areas are lacking.

In addition to Article 83(2) TFEU, Article 325(4) TFEU has been interpreted as an ancillary legal basis for EU-level criminalisation in the specific area of EU-fraud. As stated earlier, EU-fraud concerns an offence category that has been mentioned on the list of offences for which double criminality may no longer be required.

4. Double criminality and the territoriality clause in mutual recognition instruments

It follows from the discussion above that in a considerable number of crime areas that qualify for the adoption of EU-level criminal prohibitions (at least the areas covered by Articles 83(1) and 325 TFEU), the mere existence of differing scopes of national criminal prohibitions have become irrelevant for determining whether cooperation requests should be complied with; because double criminality may no longer be required in these many areas of crime, divergences in the scopes of crime definitions do not constitute a reason as such to decline mutual recognition. Such divergences may only count insofar as they occur in situations where the (alleged) offence has partly or wholly been committed outside the territory of the issuing Member State. If in such a case the executing Member State would not have had jurisdiction itself would the offence have been committed outside its own territory (which will obviously be the case where the underlying offence has not been criminalised in the executing Member State), it may decide to decline recognition under some of the instruments; this applies to European arrest warrants, confiscation orders, financial penalties. ${ }^{78}$ Moreover, if a European investigation order relates to conduct that allegedly has been displayed outside the territory of the issuing Member State, but, partly or wholly on the territory of the executing Member State, and this conduct does not constitute a criminal offence in this latter Member State, it is allowed to refuse the carrying out of the investigative measure. ${ }^{79}$

\section{EU-level Criminalisation to Prevent Forum Shopping and to Facilitate Judicial Cooperation?}

Based on the previous findings, this section examines the extent to which differences in scopes of national criminal prohibitions may hinder judicial cooperation and leave opportunities for forum shopping by criminals - and whether equal definitions of offences would smoothen judicial cooperation and better prevent forum shopping.

78 See respectively: Framework Decision 2002/584/JHA on the European arrest warrant (fn. 49), Article 4(7)(b); Framework Decision 2006/783/JHA (fn. 58), Article 8(2)(f); and Framework Decision 2005/214/JHA (fn. 59), Article 7(2)(d)(ii).

79 Directive 2014/41/EU (fn. 68), Article 11(1)(e). 
The mere fact that, under the mutual recognition regime, cooperation can hardly be declined on the very ground that the underlying offence does not constitute a criminal offence in the domestic legal order, means that the adoption of EU-level criminal prohibitions for the aim of smoother judicial cooperation is hard to defend, at least in the areas of crime that are covered by Articles 83(1) and 325 TFEU, but also in several (potential) crime areas that fall under the scope of Article 83(2) TFEU. As Section II has demonstrated, almost all of the crime areas in which the EU has been exercising its criminalisation powers since the entry into force of the Lisbon Treaty fall into these categories: cybercrime, human trafficking, child sexual abuse ${ }^{80}$, and EU-fraud ${ }^{81}$. Only the market abuse directive ${ }^{82}$ falls out of it; because market abuse has not been mentioned on the list of offences, mutual recognition can still be made subject to the double criminality requirement if the underlying offence amounts to market abuse. To enact common definitions of offences in this area of crime could, for that reason, make a real difference in cooperation practices between EU Member States. With regard to the other areas of crime, however, double criminality has been abolished to a large extent. It might be true that common definitions of criminal offences would make requests for mutual recognition of foreign judicial decisions easier to digest. But the end result would be equal, for irrespective of whether or not the underlying criminal offence constitutes a criminal offence in the executing Member State, the foreign judicial decision has to be recognised and enforced as if it were handed down in the domestic legal order.

Now, it cannot be ignored that in some of the mutual recognition instruments, the double criminality has got back in by the backdoor. As already mentioned, Member States have been allowed to uphold double criminality as a prerequisite for the recognition and enforcement of foreign custodial sanctions, alternative sanctions, probation measures, and supervision measures. It has been shown that a number of Member States have indeed made use of this opportunity. ${ }^{83}$ True as it may be that the optional reestablishment of the double criminality requirement expresses the existence of negative feelings about the further implementation of the mutual recognition principle ${ }^{84}$, its consequences should not be overestimated. Particularly with regard to supervision measures as well as probation decisions and alternative sanctions, it has only been a limited number of Member States that has declared to preserve the double criminality requirement. Moreover, it must be acknowledged that with regard to these types of judicial decisions, a refusal of recognition will hardly ever be a serious obstacle to the continuation of criminal proceedings; the issuing Member State keeps its competence to undertake the supervision of the measures imposed itself. The same applies in the context of prisoner transfer; though not less than 12 Member States have declared to apply the double criminality principle to foreign custodial sanctions, a refusal to do so

80 Section II.1.

81 Section II.3.

82 Section II.2. It concerns Directive 2014/57/EU (fn. 28).

83 See Section III.2.

84 Klip (fn. 54), p. 407.

EuCLR Vol. 7, 1/2017 
does not hinder that justice is served, that is to say in the Member State in which the custodial sanction has been handed down. Overall, the fact remains that only in a limited number of situations, divergences in scopes of criminalised behaviour are a decisive factor to the detriment of judicial cooperation between Member States.

The fact that in most situations double criminality may no longer be verified has also reduced criminals' opportunities for forum shopping across the European Union. The phenomenon of forum shopping by offenders comprises two aspects. Firstly, differences in national criminal laws may cause people to choose the most favourable Member State to carry out the intended activities. It needs no explanation that differences in scopes of criminal prohibitions and sanction levels are considered most relevant in this regard; from the perspective of (potential) criminals, the best places to go would be those Member States where substantive criminal laws are less extensive and where punishment levels are more lenient than in other Member States. Secondly, based on legislative differences across the Member States, suspected or convicted persons may try to escape justice by fleeing from the Member State where they (allegedly) committed the criminal activities to a Member State where these activities are not criminally prohibited. That way suspects could try to run away from being prosecuted and tried, and convicted persons could seek to avoid punishment.

But under the mutual recognition regime, the possibilities for criminals to benefit from differing scopes of criminal prohibitions have clearly been diminished, at least in the areas of crime that fall under the scopes of Articles 83(1) and 325 TFEU, but also in some areas of crime that are covered by Article 83(2) TFEU; it has been demonstrated that in these areas of crime, the double criminality requirement has largely been abolished. Especially where it concerns the second aspect of forum shopping - i.e. the attempt to escape justice by hiding on the territory of a Member State other than where the crime has (allegedly) been committed - shopping efforts hardly make any sense. After all, under the mutual recognition regime, the Member State to which a suspect or convicted person has resorted to, would in most cases be obliged anyhow to comply with an incoming request for cooperation if the underlying offence falls into the abovementioned crime categories.

Where it concerns the first aspect of forum shopping - i.e. moving to a Member State with more lenient criminal laws to carry out criminal activities there - the picture is a little more complicated. The most likely situation to arise in this regard is that a person X travels from his home Member State A to another Member State B for the aim of carrying out certain activities (e.g. the production and online sale of virtual child pornography) that are not criminal according to the national laws of Member State B. How likely is it that X stays secure from all prosecution? As long as Member State $\mathrm{A}$, the home state of $\mathrm{X}$, is unaware of his involvement in the production and sale of virtual child pornography on the territory of Member State B, nothing will happen. But as soon as Member State A got informed of X's activities it has several means available to investigate the case and institute criminal proceedings - provided of course that it has jurisdiction over the crimes allegedly committed abroad by its own nationals. 
The first option for Member State A would be to issue a European arrest warrant in order to have $\mathrm{X}$ surrendered for the purpose of prosecuting him. In principle, Member State B would not be allowed to refuse surrender on the sole ground that virtual child pornography has not been criminalised in its domestic legal order; since it concerns a so-called 'list offence', the double criminality requirement does not apply. However, things become a little complicated because of the territoriality clause laid down in Article 4(7)(b)FD EAW. ${ }^{85}$ As already shown in Section III.4, this provision would enable Member State B to decline surrender and to drop the matter: the production and online sale of virtual child pornography has been committed outside the territory of Member State A, and Member State B would not have been able to prosecute these acts if committed elsewhere, simply because Member State B cannot exercise jurisdiction over facts that have not been criminalised through its own laws. Clearly, in a situation like this $\mathrm{X}$ could in fact benefit from deviant definitions of sexual offences in Member State B.

The same room for forum shopping would exist where Member State A would decide to administer justice in the absence of defendant $\mathrm{X}$, and, after the closing of criminal proceedings, would issue a European arrest warrant for the purpose of executing the sanction that has been imposed on X - a second means Member State A has at its disposal. Here, the territoriality clause of Article 4(7)(b)FD EAW would apply accordingly, as a result of which $\mathrm{X}$ could indeed be secured from being sentenced due to the fact that the offence underlying his conviction in Member State A does not constitute a criminal offence in Member State B.

A third means that in the near future would be available to Member State A in a case such as in the given example is the issuance of a European investigation order to have certain investigative measures carried out in Member State A (such as the searching of X's premises or his personal computer). Although the double criminality requirement has been abolished for almost all investigative measures to be carried out in relation to the 32 listed offences, it is again a territoriality clause that does provide the possibility for criminals to take advantage from divergent scopes of national criminal prohibitions. Article 11(1)(e) of the Directive on the European Investigation Order (hereinafter: EIO Directive) $)^{86}$ would enable Member State B to refuse to carry out the investigative measures requested by Member State A because the production and online sale of virtual child pornography took place outside Member State A, but on its own territory, and these activities have not been criminalised in its domestic legal order.

In spite of the far-reaching obligations under the mutual recognition principle to execute judicial decisions coming from other Member States, the foregoing demonstrates that forum shopping is possible under some of the cooperation instruments. In those areas of crime where the scopes of national criminal prohibitions diverge, it can make sense to move to a Member State where the intended criminal activities will not breach national criminal laws. Even if such activities fall under the scope of one or more crime

85 Framework Decision 2002/584/JHA (fn. 56).

86 Directive 2014/41/EU (fn. 68).

EuCLR Vol. 7, 1/2017 
categories for which double criminality may not be verified, the commission of these activities on the territory of a Member State where they are not considered to be criminal activities, would enable this Member State to refuse recognition of a European arrest warrant, European investigation order, a confiscation order or a foreign financial penalty. ${ }^{87}$ That way, criminals would stay secure from adjudication.

However, although it is true that the aforementioned possibility of forum shopping would disappear with the adoption of equal definitions of offences - then, these territoriality clauses could no longer be invoked - their effect on forum shopping opportunities should not be overestimated. As to Article 4(7)(b) FD EAW, there are strong indications that this refusal ground is rarely invoked. ${ }^{88}$ It remains to be seen how this goes for the territoriality clauses in the other mutual recognition instruments. However, from a historical perspective, it seems illogical to assume a wide application of this territorially clause in the context of mutual legal assistance; refusal grounds related to territoriality have not been envisaged in traditional mutual legal assistance instruments. ${ }^{89}$ Combined with the fact that such refusal grounds have only been included in a very limited number of mutual recognition instruments, and where they have "only" create the option to refuse - thus, it is up to the executing Member State whether or not to invoke it - the overall effects of equal definitions of criminal prohibitions on forum shopping opportunities should not be overestimated.

87 See Section III.4.

88 This follows from statistics on the application of the European arrest warrant over 2009-2013: Council General Secretariat, Note to the Working Party on Cooperation in Criminal Matters, Replies to questionnaire on quantitative information on the practical operation of the European arrest warrant - Year 2009, Council doc. 7551/5/10, Annex 1, p. 21-26; Council General Secretariat, Note to the Working Party on Cooperation in Criminal Matters, Replies to questionnaire on quantitative information on the practical operation of the European arrest warrant - Year 2010, Council doc. 9120/11, Annex 1, p. 22-25; Council General Secretariat, Note to the Working Party on Cooperation in Criminal Matters, Replies to questionnaire on quantitative information on the practical operation of the European arrest warrant - Year 2011, Council doc. 9200/7/12, Annex 1, p. 22-27; Council General Secretariat, Note to the Working Party on Cooperation in Criminal Matters, Replies to questionnaire on quantitative information on the practical operation of the European arrest warrant Year 2012, Council doc. 7196/2/13, Annex 1, p. 22-25; Council General Secretariat, Note to the Working Party on Cooperation in Criminal Matters, Replies to questionnaire on quantitative information on the practical operation of the European arrest warrant - Year 2013, Council doc. 8414/4/14, Annex 1, p. 22-28. See also G. Vernimmen-Van Tiggelen/L. Surano, Analysis of the future of mutual recognition in criminal matters in the European Union, Final Report, 2008,p. 13-14.

89 Vernimmen-Van Tiggelen/Surano (fn. 88), p. 14. Based on interviews with experts, the authors have made this point with regard to the territoriality clause that was laid down in Framework Decision 2008/978/JHA (fn. 67), the predecessor instrument of Directive 2014/41/EU (fn. 68) on the European Investigation Order. 


\section{Conclusion}

In exercising its criminalisation powers under the Lisbon Treaty, the prevention of forum shopping by criminals and the facilitation of judicial cooperation have been invoked to underpin the adoption of EU-level criminal prohibitions in several areas of crime. In this paper, it has been examined whether and to what extent both aims can reasonably be relied on. It has been demonstrated that under the mutual recognition regime, differing scopes of national criminal prohibitions have largely become irrelevant in as much as 32 areas of crime: if the criminal act that underlies a mutual recognition request falls under one of these crime areas, double criminality may not be verified. This paper shows that this list of 32 crime areas covers all the areas of crime enumerated in Articles 83(1) and 325 TFEU and also some of the areas that fall under the scope of Article 83(2) TFEU.

The exercise of criminalisation powers under the headings of Articles 83(1) and 325 TFEU can, therefore, not convincingly found on the argument that equal definitions of offences are needed to avoid forum shopping and to facilitate judicial cooperation; in by far most cases, Member States are obliged to comply with requests for mutual recognition, irrespective of whether the underlying offences constitute a crime in the domestic legal order. While it is true that in the absence of double criminality the territoriality clause leaves some room for forum shopping, the rare application of this optional refusal ground cannot suffice to support the claim that EU-level criminal prohibitions are needed to prevent forum shopping activities.

All in all, the extensive possibilities to cooperate transnationally and the far-reaching obligations under the mutual recognition principle have made it quite hard to find a safe haven across the European Union. Therefore, as it currently stands it cannot convincingly be claimed that EU-level criminal prohibitions on the basis of Articles 83(1) and 325 TFEU, and to some extent neither on the basis of Article 83(2) TFEU, are needed to facilitate judicial cooperation and to avoid forum shopping. 